\title{
Extraluminal nitinol prosthesis in the treatment of intrathoracic tracheal collapse in a dog
}

\author{
Paloma Helena Sanches da Silva ${ }^{1}$ (i) Mariana Zanini Maia ${ }^{1^{*}}$ (D) Danyelle Rayssa Cintra Ferreira ${ }^{1}$ (B) \\ Bruno Canedo Simões de Lima $^{1}$ (i) Amanda Oliveira Paraguassú1 ${ }^{\text {(D) }}$ Marcelo Rezende Luz ${ }^{1}$ (i) \\ Suzane Lilian Beier ${ }^{1}$ (B) Patrícia Maria Coletto Freitas ${ }^{1}$ (i)
}

${ }^{1}$ Departamento de Clínica e Cirurgia Veterinárias, Universidade Federal de Minas Gerais (UFMG), 31270-901, Belo Horizonte, MG, Brasil. E-mail: mzaninimaia@hotmail.com. "Corresponding author.

ABSTRACT: A six-month-old male Brazilian Terrier with persistent cough and dyspnea was diagnosed with intrathoracic tracheal collapse and pneumonia after chest radiographics. The medical treatment was performed, and an extraluminal nitinol prosthesis was placed through thoracic access. The dog did not presented recurrence of dyspnea or pneumonia for four years after the surgical procedure. Placement of the extraluminal prosthesis with the thoracic approach effectively stabilized intrathoracic tracheal collapse without causing any structural damage in the thoracic region. Therefore, this is the first report of a successful use of this prosthesis with an intercostal approach in dogs for intrathoracic trachea collapse.

Key words: airways, degeneration, metal alloy, tracheomalacia.

Uso de prótese extraluminal de nitinol no tratamento de colapso traqueal intratorácico em um cão

RESUMO: Um cão macho, da raça Terrier Brasileiro de seis meses de idade, com dispnéia e tosse persistente foi diagnosticado com colapso traqueal intratorácico e pneumonia após estudo radiográfico de tórax. Foi instituído tratamento médico e realizada toracotomia para a implantação de prótese traqueal extraluminal de nitinol. O animal não manifestou dispneia ou pneumonia durante os quatro anos posteriores ao procedimento. A implantação da prótese extraluminal através da toracotomia foi eficaz para o tratamento do colapso traqueal intratorácico, sem provocar danos estruturais na região torácica. Desta forma, este é primeiro relato da utilização bem-sucedida deste tipo de prótese, a partir da abordagem intercostal, no tratamento de cães com colapso traqueal intratorácico.

Palavras-chave: vias aéreas, degeneração, liga metálica, traqueomalácia.

Tracheal collapse is a common medical condition that can lead to respiratory distress in dogs (SIGRIST et al., 2010). It is characterized by the degeneration of the tracheal cartilage rings and muscle tracheal resistance loss, resulting in dorsoventral flattening of the trachea. It can occur in both cervical and thoracic tracheal segments (TAPPIN, 2016). Dry and paroxysmal cough, described as "goosehonking," are the most common clinical signs. Imaging modalities, such as radiography, fluoroscopy, computed tomography, and tracheobronchoscopy, can be used for the diagnosis (BOTTERO, et al., 2013; TAPPIN, 2016). Many methods of treatment have been suggested, including medical management and provision of extraluminal and intraluminal support. Surgical intervention is only indicated for higher-grade collapses (TANGNER \& HOBSON, 1982) unresponsive to clinical treatment
(ROSENHECK et. al., 2017). Surgical management includes the placement of intraluminal (migration is of common occurrence) or extraluminal prosthesis (TAPPIN, 2016), which can be C-shaped or spiral, made of polypropylene or nitinol, indicated for the correction of cervical tracheal collapse. However, a polypropylene spiral prosthesis has already been used experimentally in the intrathoracic tracheal segment of dogs (FINGLAND et al., 1989), but nitinol prosthesis has never been reported as an alternative method to approach intrathoracic tracheal collapse.

In this present case, we reported the successful use of a spiral extraluminal nitinol prosthesis to treat intrathoracic tracheal collapse in a dog, using a thoracic approach.

A six-month-old intact male Brazilian Terrier weighing $5 \mathrm{~kg}$ was evaluated after presenting cough for 2 months triggered by excitement. The 
patient had been treated with prednisolone $(0,5 \mathrm{mg} /$ $\mathrm{kg} / \mathrm{q} .12 \mathrm{~h} \mathrm{IV}$ ) and amoxicillin with clavulanic acid (20 $\mathrm{mg} / \mathrm{kg} / \mathrm{q} .12 \mathrm{~h} \mathrm{IV}$ ) with no medical response. Clinical signs included expiratory dyspnea and pulmonary auscultation with a hissing crackle in the caudal pulmonary lobes. Cervical and thoracic radiographs were acquired in lateral projections, and hematologic tests were performed. Intrathoracic tracheal collapse was diagnosed from the lateral chest X-ray findings (Figure 1) of advanced tracheal collapse due to a considerable decrease in the tracheal lumen in addition to pneumonia. As he had dyspnea and pneumonia, the patient was admitted for clinical treatment with intravenous antibiotic therapy and support treatment until clinical and laboratory improvements were achieved before surgical correction of the collapse.

The surgical procedure consisted in placement of a nitinol spiral extraluminal prosthesis in the thoracic tracheal segment from a chest approach (InTrak, Model: helix shape Ni-Ti (thickness 0.9mm
/ diameter $10 \mathrm{~mm} /$ length $40 \mathrm{~mm}$ ) manufacturer: InPulse Animal Health Brazil, https://inpulse.vet.br). Size of the prosthesis was chosen taking into account the measurement obtained after the lateral-lateral thoracic radiographic examination (K-PACS - Dicom Image Viewer, System software), performed during the patient's inspiration movement (Figure 2). With this radiograph, it could be determined that the affected tracheal segment had, at its maximum distension, a diameter of approximately $0.94 \mathrm{~cm}$, in addition to a length of $3.8 \mathrm{~cm}$ referring to the collapsed segment. For this, an extraluminal prosthesis was used with a size of $10 \times 40 \mathrm{~mm}$, that is, $1.0 \mathrm{~cm}$ in diameter and $4.0 \mathrm{~cm}$ in length.

Surgical procedure was performed under general anesthesia with propofol 2,0mg/Kg IV (Fresofol 1\%, Fresenius Kabi Brasil Ltda, Campinas, São Paulo, Brazil) and isoflurane (Isothane, Baxter Hospitalar Ltda., Santo Amaro, São Paulo, Brazil). A paravertebral block with bupivacaine (Neocaína

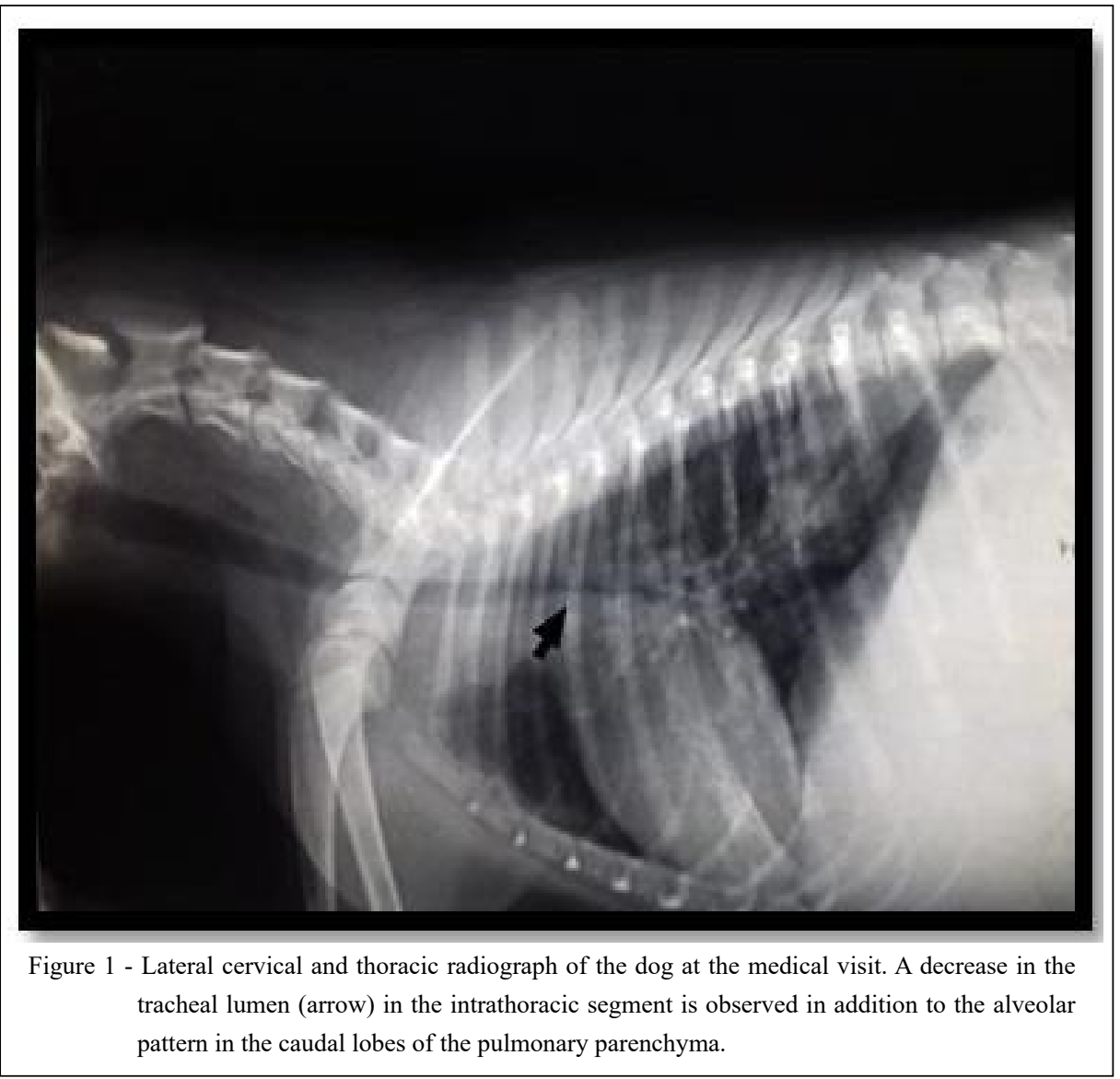

Ciência Rural, v.52, n.9, 2022. 


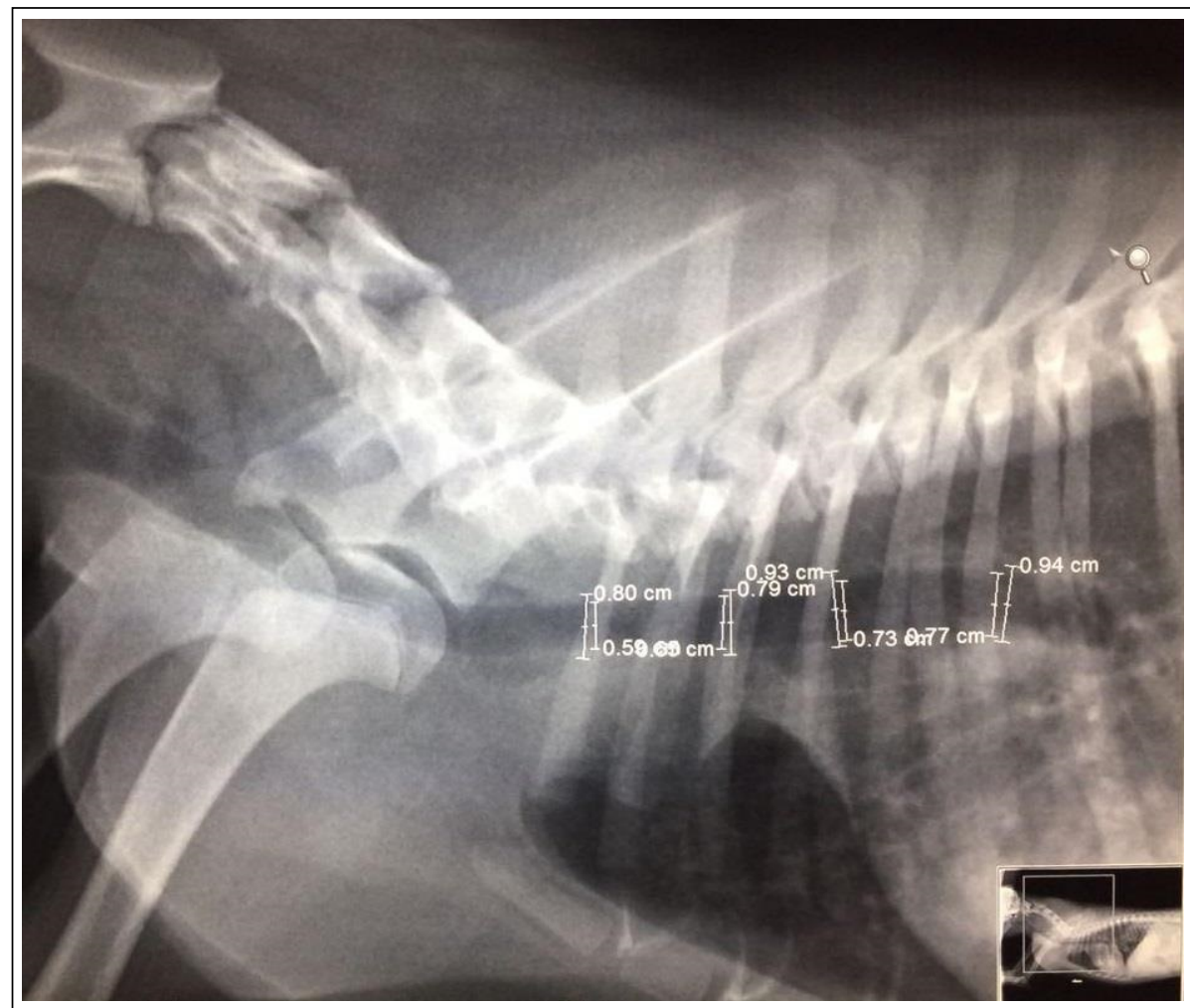

Figure 2 - Latero-lateral radiographic image of the dog's cervical and thoracic regions, with tracheal collapse, showing measurements in $\mathrm{cm}$ of the tracheal diameter during inspiration when the patient was 6 months old and was submitted to the surgical procedure.

0,5\%, Cristália, São Paulo, São Paulo, Brazil) was performed and analgesia with infusion of fentanyl $7.5 \mathrm{mcg} / \mathrm{kg} / \mathrm{h}$ IV (Fentanest, Cristália Ltda., São Paulo, São Paulo, Brazil) associated with ketamine $10 \mathrm{mcg} / \mathrm{kg} / \mathrm{min}$ IV (Ketamin S - Cristália Ltda., São Paulo, São Paulo, Brazil) was prepared for the transoperative period. After trichotomy and antisepsis of the right lateral chest, the animal was placed on left lateral decumbency, and intercostal thoracotomy was performed in the third intercostal space.

Under visualization, the intrathoracic tracheal segment was segmentally dissected, avoiding damage to the important neurovascular structures. Delicate and meticulous dissection of the paratracheal tissue from fenestrations performed using a curved hemostat, the nitinol spiral prosthesis was inserted from the cranial portion of the intrathoracic trachea to the caudal portion, which progressed to involve the tracheal rings circumferentially avoiding incarceration of the recurrent laryngeal nerves between the implant and the trachea.
During the progression, slight tracheal traction was necessary for the prosthesis placement in the collapsed segment (Figure 3) and movement of the endotracheal tube occurred, hindering the device's placement, since the tube occupied the space inside the trachea. As a result, the tube had to be retracted cranially so that the passage of the prosthesis could be completed. Consequently, a tracheal segment remained collapsed for approximately $5 \mathrm{~min}$ before the reestablishment of oxygenation.

After the prosthesis placement and verification of the integrity of the adjacent structures, we performed thoracorraphy with a 0 polyglecaprone 25 suture and Sultan pattern, myorrhaphy with 2-0 polyglecaprone 25 suture and simple continuous pattern, subcutaneous suture with 3-0 polyglecaprone 25 suture and simple continuous pattern, and dermorraphy with 3-0 nylon suture and simple interrupted pattern. The patient remained hospitalized after surgery and received cefalotin (Cefalotina Sódica, antibióticos do Brasil, Cosmópolis, São

Ciência Rural, v.52, n.9, 2022. 


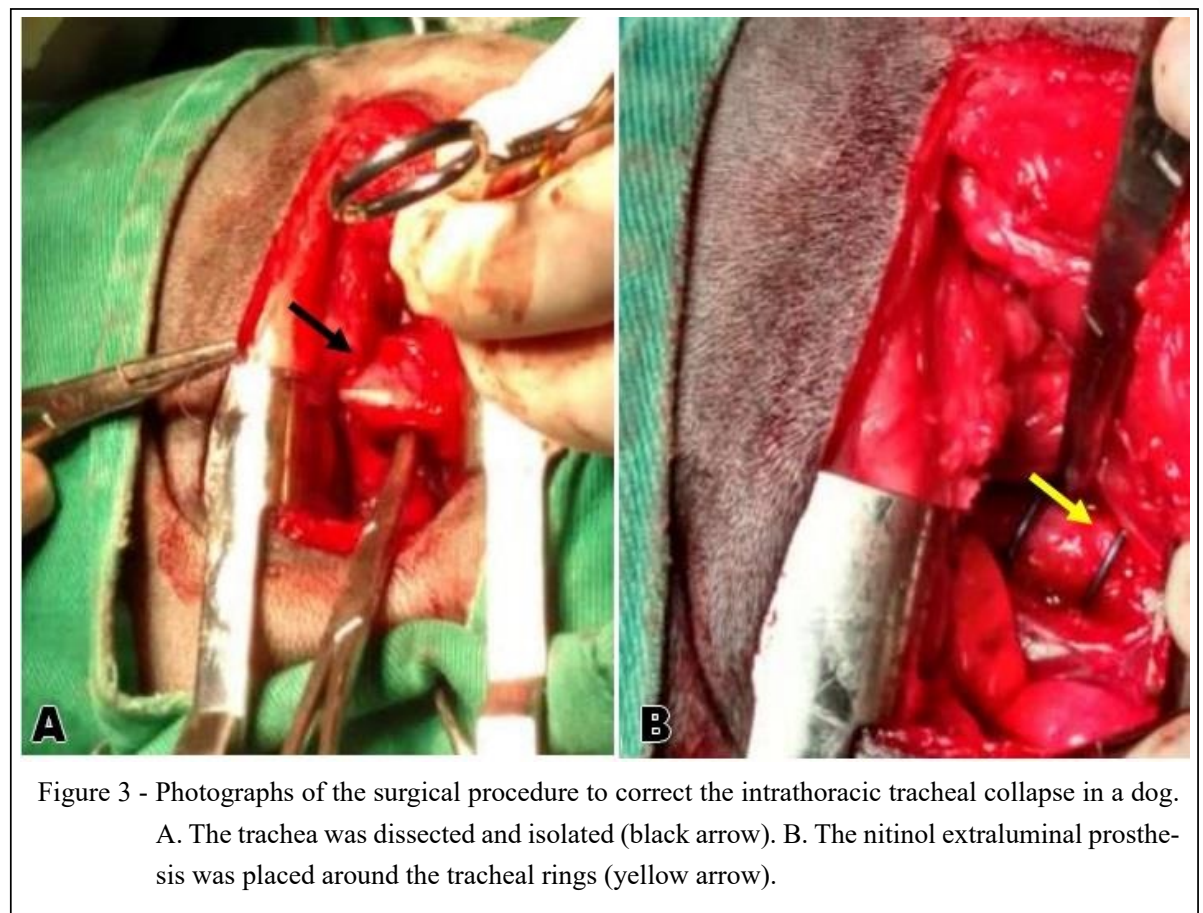

Paulo, Brazil) (30 mg/kg/q. 8 h IV), prednisolone (Prednisolona 5mg, Eurofarma Laboratórios S.A, Itapevi, São Paulo, Brazil) (0.5 mg/kg/q. 12 h PO), and acetylcysteine (Acetilcisteína, Eurofarma Laboratórios S.A, Itapevi, São Paulo, Brazil) (10 mg/ $\mathrm{kg} / \mathrm{q} .12 \mathrm{~h} \mathrm{PO}$ ), and for systemic analgesia, methadone (Mytedon, Cristália, São Paulo, Brazil) $(0.3 \mathrm{mg} / \mathrm{kg} / \mathrm{q}$. $6 \mathrm{~h} \mathrm{IM}$ ) and ketamine (Cetamin, Syntec, Barueri, São Paulo, Brazil) (1.0 mg/Kg/q. 6 h IM).

At $24 \mathrm{~h}$ postoperatively, a radiograph was acquired to check the prosthesis placement. On postoperative day 2, opioids and local anesthetics were replaced with tramadol hydrochloride (Cloridrato de Tramadol, União Química Farmacêutica Nacional S/A, Jabaquara, São Paulo, Brazil) $(5,0 \mathrm{mg} / \mathrm{kg} / \mathrm{q}$. $8 \mathrm{~h} \mathrm{IM}$ ) and dipyrone (Analgex V, União Química Farmacêutica Nacional S/A, Jabaquara, São Paulo, Brazil) $(25 \mathrm{mg} / \mathrm{kg} / \mathrm{q} .8 \mathrm{~h} \mathrm{IV})$. On postoperative day 30 , the patient was discharged from hospital. Radiographic follow-up was scheduled every 15 days for 8 months (Figure 4). The prosthesis had no displacement during the follow-up period. In addition, the animal no longer had dyspnea or pneumonia. The dog was followed-up for 4 years after the procedure, with no clinical signs.

In the present case reported, surgery to place the extraluminal prosthesis was indicated for the patient diagnosed with intrathoracic tracheal collapse based on clinical and radiographic findings and not responsive to conservative treatment. The preoperative examination of tracheobronchoscopy; although, considered the gold standard for diagnosis, in addition to enabling the definition of the degree of the disease (TAPPIN, 2016) was not authorized by the tutor due to financial constraints.

When placing the spiral prosthesis in the trachea, complications, such as laryngeal paralysis, may occur in up to $30 \%$ of cases (TINGA et al., 2015), which was not observed in the animal in this report. This can be explained by thorough paratracheal tissue dissection after identification of the nerve structures without traumas, such as precise placement of the implant externally to the trachea. Tracheal necrosis is another complication described after spiral prosthesis placement (KIRBY et al., 1991), since the trachea has segmental vascularization, which can be impaired with the use of an extraluminal prosthesis. In the present case, fenestrations performed in the paratracheal tissue for the prosthesis insertion may have allowed preserving the organ vascularization.

The patient in the case report; although, aged six months when he underwent surgery for placement of the prosthesis, had already started sexual maturity 


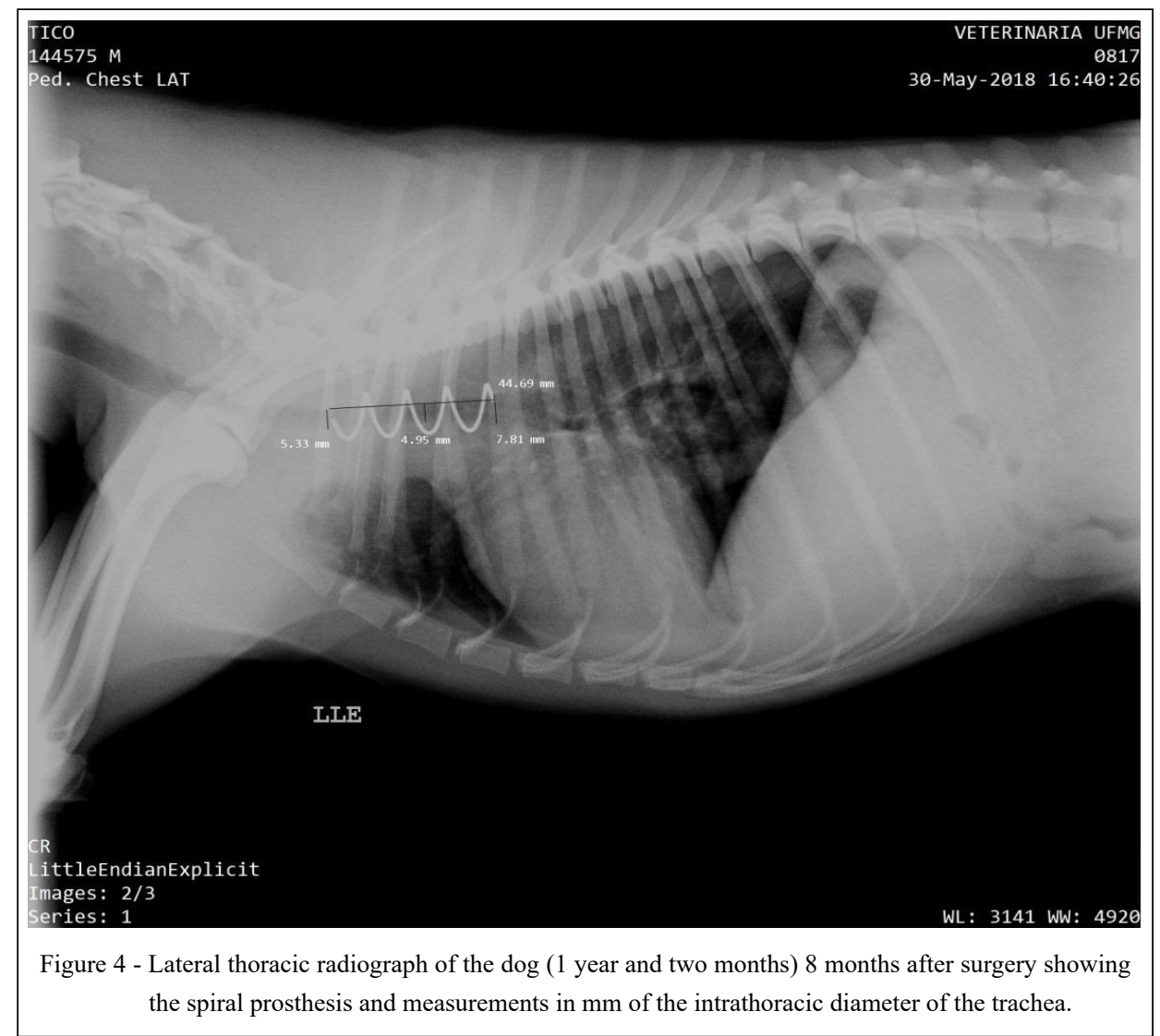

and had weight and body size approximate to that of an adult dog for the breed standard, which could reduce the risk of tracheal stenosis as a complication. In addition, the authors also placed an extraluminal prosthesis with a larger diameter (prosthesis diameter $1.0 \mathrm{~cm}$ ) than the patient's intrathoracic trachea diameter (approximately $0.9 \mathrm{~cm}$, obtained on inspiration) presented at six months of age, at the time surgery, thus minimizing the risk of tracheal stenosis. Thus, in the last radiographic examination of the patient at 1 year and 2 months of age, that is, 8 months after surgery (Figure 4 ), it is possible to notice similarity of the tracheal diameter when compared to the radiographic examination of the intrathoracic trachea, before the placement of the prosthesis, when the patient was 6 months old (Figure 2).

The extraluminal prosthesis placement with a thoracic surgical approach was effective in stabilizing the collapse without causing any thoracic structural damage. Besides the facility of the prosthesis placement and its low cost when compared to intraluminal stents, the nitinol is biocompatible and has the properties of thermal shape memory and super elasticity that make it ideal for surgical prosthesis (BARRAS et al., 2000). To the authors, this is the first report of the use of nitinol prosthesis to treat intrathoracic tracheal collapse in a dog, with intercostal access, providing a new method of supporting intrathoracic tracheal in the species.

\section{ACKNOWLEDGEMENTS}

To the Ministry of Education for offering scholarships for the multidisciplinary residency program for the team involved in this case and was financed in part by the Coordenação de Aperfeiçoamento de Pessoal de Nível Superior (CAPES), Brasil - Finance code 001.

\section{DECLARATION OF CONFLICT OF} INTERESTS

The authors declare no conflict of interest.

\section{AUTHORS' CONTRIBUTIONS}

The authors contributed equally to the manuscript. 


\section{REFERENCES}

BARRAS, C.D.J.; MYERS, K.A. Nitinol - Its use in vascular surgery and other applications. European Journal and Endovascular Surgery, v.19(6), p.564-569. 2000. Available from: $<$ https://www.ejves.com/article/S1078-5884(00)91111-0/pdf $>$. Acessed: Jan. 21, 2021. doi:10.1053/ejvs.2000.1111.

BOTTERO, E. et al. Clinical evaluation and endoscopic classification of bronchomalacia in dogs. Journal of Veterinarian Internal Medicine, v.27(4), p.840-846. 2013. Available from: $<$ https://onlinelibrary.wiley.com/doi/full/10.1111/jvim.12096>. Acessed: Jan. 21, 2021. doi: 10.1111/jvim.12096.

FINGLAND, R.B. et al. Clinical and pathologic effects of spiral and total ring prostheses applied to the cervical and thoracic portions of the trachea of dogs. American Journal of Veterinarian Research, v.50(12), p.2168-2175. 1989. Available from: <https:// pubmed-ncbi-nlm-nih.ez27.periodicos.capes.gov.br/2692485>. Acessed: Jan. 21, 2021.

KIRBY,B.M. et al. The effects of surgical isolation and application of polypropylene spiral prostheses on tracheal blood flow. Veterinary Surgery, v.20(1), p.49-54. 1991. Available <from:https:// onlinelibrary.wiley.com/doi/10.1111/j.1532-950X.1991.tb00305. $\mathrm{x}>$. Acessed: Jan. 21, 2021. doi: 10.1111/j.1532-950x.1991. tb00305.x.

ROSENHECK, S. et al. Effect of Variations in Stent Placement on Outcome of Endoluminal Stenting for Canine Tracheal Collapse.
Journal of American Animal Hospital Association, v.53(3), p.1-9. 2017. Available from: <https://jaaha.org/doi/full/10.5326/ JAAHA-MS-6485>. Acessed: Jan. 21, 2021. doi: 10.5326/ JAAHA-MS-6485.

SIGRIST, N. et al. Evaluation of respiratory parameters at presentation as clinical indicators of the respiratory localization in dogs and cats with respiratory distress. Journal of Veterinary Emergency and Critical Care, V.21(1), p.13-23. 2010. Available from: <https:// onlinelibrary-wiley.ez27.periodicos.capes.gov.br/doi/full/10.1 111/j.1476-4431.2010.00589.x>. Acessed: Jan. 21, 2021. doi: 10.1111/j.1476-4431.2010.00589.x.

TANGNER, C.; HOBSON H. A retrospective study of 20 surgically managed cases of collapsed trachea. Veterinary Surgery, v.11(4), p.146-149.1982. Available from: <https://onlinelibrary.wiley.com/ doi/abs/10.1111/j.1532-950X.1982.tb00691.x>. Acessed: Jan. 21, 2021. doi: 10.1111/j.1532-950X.1982.tb00691.x.

TAPPIN, S. Canine tracheal collapse. Journal of Small Animal Practice, v.57, p.9-17.2016. Available from: $<$ https://onlinelibrary. wiley.com/doi/full/10.1111/jsap.12436>. Acessed: Jan. 21, 2021. doi:10.1111/jsap. 12436 .

TINGA, S. et al. Comparison of outcome after use of extra-luminal rings and intra-luminal stents for treatment of tracheal colapse in dogs. Veterinary Surgery, v.44(7), p.858-865. 2015. Available from: <https://pubmed.ncbi.nlm.nih.gov/26249528/>. Acessed: Jan. 21, 2021. doi: 10.1111/vsu. 12365. 